\title{
Use of Electronic Nicotine Delivery Systems (ENDS) in Poland in 2019
}

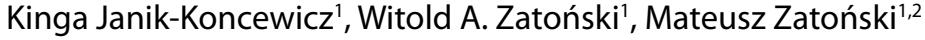 \\ 'Institute - European Observatory of Health Inequalities, Calisia University, Kalisz, Poland \\ ${ }^{2}$ Tobacco Control Research Group, Department for Health, University of Bath
}

\begin{abstract}
Background: The introduction of Electronic Nicotine Delivery Systems (ENDS) was suspected to be a factor disrupting the stable decline in the nicotine and tobacco market in Poland.

Materials and method: A cross-sectional study was conducted in 2019 on a representative sample of 1077 Polish adults aged 18 years and used face-to-face interviews. ENDS use was analysed from respondents aged 20 years and older by gender, age, place of residence and education. Calculations were done using IBM SPSS Statistics 25.

Results: Only 3.0\% of men and 0.7\% of women in Poland were daily (regular) ENDS users in 2019, while $1.6 \%$ of men and $0.7 \%$ of women were occasional users. The vast majority of respondents ( $97 \%$ ) declared that they did not use ENDS at all. ENDS use was most prevalent in the youngest age group (5.3\% in men, $1.3 \%$ in women), and in urban than rural areas (4.1\% of men and $0.9 \%$ of women in urban areas vs $1.5 \%$ of men and $0.5 \%$ of women in rural areas), in men with a secondary education $(4.3 \%)$, and in women with a primary education (1.2\%). Three percent of men (3.1\%) were daily (regular) dual users of conventional cigarettes and ENDS, and 3.5\% of men using conventional cigarettes used ENDS in exceptional situations (occasionally). Conclusions: Our study showed that despite a decline in conventional cigarette smoking, the prevalence of ENDS use among adults in Poland is low and it did not increase in the recent years. This stands in contrast with research showing that Poland has some of the highest rates of ENDS use among children. However, the system of monitoring of ENDS use in Poland needs to be improved, as the existing data for Poland remains scattered, of poor quality, and based on small samples.
\end{abstract}

KEY WORDS: Poland, e-cigarettes, Electronic Nicotine Delivery Systems (ENDS), nicotine delivery device.

ADDRESS FOR CORRESPONDENCE: Kinga Janik-Koncewicz, Institute - European Observatory of Health Inequalities, Calisia University, Nowy Świat 4, 62-800 Kalisz, Poland. e-mail: k.janik-koncewicz@akademiakaliska.edu.pl

\section{INTRODUCTION}

Poland historically had some of the highest levels of tobacco consumption in the world in the 1980s [1]. The introduction of Electronic Nicotine Delivery Systems (ENDS) was suspected to be a factor disrupting this stable decline in the nicotine and tobacco market in Poland.

In the 21 st century tobacco control has been increasingly striving towards finding avenues to facilitate an endgame of tobacco use. The interest in cigarettes is rapidly decreasing in many countries, and Poland is a country which illustrates this phenomenon well. Tobacco sales declined from 100 billion of cigarettes in mid 1980s to 40 billion in 2017. This corresponds with the decreasing consumption of cigarettes per capita per annum from almost 4,500 cigarettes in 1980s (one of the highest levels ever recorded globally) to under 1,500 cigarettes in 2015. One of the latest analysis of smoking prevalence in Poland showed a decline in smoking prevalence from $73 \%$ in 1976 to $27 \%$ in 2019 in men, and from $30 \%$ in 1982 to $18 \%$ in 2019 in women [2-4]. Recent data showed that there is around 7 million daily smokers in Poland [2]. This has been followed by a significant decrease in the incidence and mortality of tobacco-related diseases in Poland, especially cardiovascular diseases and lung cancer [5]. Time trends in lung cancer mortality are the best and long-term indicator of tobacco 
exposure. In Poland, mortality from lung cancer shows a steady decline, especially in youngest adults (20-44 years) from $6.7 / 100,000$ in 1981 to $1.1 / 100,000$ in 2017 among men, and from $2.0 / 100,000$ in 1996 to $0.5 / 100,000$ in 2017 among women [6]. The report of the European Commission on Europeans' attitudes toward smoking demonstrated in Poland the second biggest decline among EU countries in the average number of cigarettes smoked every day between 2017 and 2020 [7, 8]. This decreasing sale and consumption of cigarettes in Poland might have driven the tobacco industry for ways to promote new nicotine products on the market, and ensure a new generation of consumers to replace those adults that have been successfully quitting nicotine use.

Growing interest in ENDS in the past decades has become a public health concern globally. There is growing evidence that ENDS use is increasing in Europe, however there is a wide variation in prevalence of ENDS use between European countries [9, 10]. Laverty et al. estimated $1.8 \%$ of the EU population (7.6 million) to be daily (regular) ENDS users [9]. The proportion of adult ENDS daily (regular) users varied in 2017 from $0.2 \%$ in Bulgaria or Italy to $4.7 \%$ in UK [11]. It is worth placing this in the context of the fact that the WHO European Region has the highest prevalence of tobacco use worldwide with around 209 million of daily adult smokers [12].

ENDS are non-combustible tobacco products designed to deliver nicotine to the human body. They are distributed under a variety of names such as electronic cigarettes (e-cigarettes), vapes, vaporizers, vape pens, hookah pens, and e-pipes and can look like conventional cigarettes, cigars or pipes, but some resemble pens or pen drives. These products usually use liquids (containing nicotine but also a composition of flavourings, propylene glycol and other ingredients) which are heated and create aerosol for inhalation $[13,14]$.

ENDS first appeared on the Polish market in 2006 [15] initially attracting interest primarily among adult smokers, but quickly becoming very popular among children and youth. Some data sources suggest that the prevalence of ENDS use in Poland was relatively high. A cross-sectional online survey conducted between 2016 and 2017 among Polish-speaking users of social networks reported $84.9 \%$ of ENDS ever users [16]. Finally, in a study by Jankowski et al. conducted between 2017 and 2018 among university students in five student hostels in Poland almost half of the respondents (45\%) declared ever use of ENDS [15]. However, none of these studies were based on representative population-based surveys. The number of nationally representative surveys on prevalence of ENDS use in adults in Poland is scarce. However, a 2019 survey carried out by the Public Opinion Research Center on a representative sample of Polish adults [2] did include questions about ENDS use. The aim of this study is to analyse the results of this survey and describe the prevalence of ENDS use in Poland in 2019.

\section{MATERIAL AND METHODS}

A cross-sectional study was conducted on 4-11 July 2019 on a representative sample of 1077 Polish adults aged 18 years and over. It was a multitask study with section devoted to using ENDS among others. The method has been already described in detail elsewhere [2]. Faceto-face interviews were carried out by the Public Opinion Research Center using the computer-assisted personal interviewing (CAPI) technique [17]. A random sample was selected from the register of personal identity numbers containing information on every Polish citizen registered in Poland. The sampling frame included stratification according to territorial localization, size of the place of residence, gender and age. The sampling frame ensured that the study sample corresponded with the structure of the general Polish population in 2019 (described elsewhere [2]).

The study questionnaire included questions on cigarette smoking (results reported elsewhere [2]) and four questions concerning ENDS. ENDS use was defined by the question: "Do you use an electronic cigarette (e-cigarette)?". If respondents answered "Yes, regularly" they were classified as daily (regular) ENDS users, if they answered "Yes, but only in exceptional situation, occasionally", they were classified as occasional ENDS users. The three remaining questions concerned knowledge on ENDS harm ("Do you think that e-cigarette use is harmful for health?"), attitudes toward bans on e-cigarette sales to the youth ("Do you support a ban on e-cigarette and accessories sale to people below 18 years old?") and towards bans on ENDS use in public places ("Do you support a ban on e-cigarette use in public places?"), and were excluded from the analysis in this study.

The present analysis focused on data concerning ENDS use. Data were analysed by gender, age, place of residence and education. We analysed data from respondents aged 20 years and older and used three age groups: 20-44 years old, 45-64 years old, and 65 and more years old. Residence was divided into two categories: rural and urban, and education into four categories: primary and incomplete, vocational, secondary and higher/academic. Additionally, we calculated the proportion of ENDS users among daily smokers of traditional cigarettes (dual users). Calculations were done using IBM SPSS Statistics 25.

\section{RESULTS}

Descriptive characteristics of the study population is presented in Table 1 . Only $3.0 \%$ of men $(n=15)$ and $0.7 \%(n=4)$ of women in Poland were daily (regular) ENDS users in 2019, while $1.6 \%$ of men $(n=8)$ and $0.7 \%$ of women $(n=4)$ were occasional users (only used ENDS in exceptional situations). The vast majority of respondents $(97 \%, n=1016)$ declared that they did not use ENDS at all (Table 2).

ENDS use was most prevalent in the youngest age group ( $5.3 \%$ in men, $1.3 \%$ in women), and least preva- 
TABLE 1. Descriptive characteristics of the study population $(N=1047)$

\begin{tabular}{|c|c|c|}
\hline Factor & $\%$ & $n$ \\
\hline \multicolumn{3}{|l|}{ Gender } \\
\hline Men & 47.4 & 496 \\
\hline Women & 52.6 & 551 \\
\hline \multicolumn{3}{|l|}{ Age } \\
\hline 20-44 years old & 43.4 & 454 \\
\hline 45-64 years old & 34.3 & 359 \\
\hline 65 years old and older & 22.3 & 234 \\
\hline \multicolumn{3}{|l|}{ Residence } \\
\hline Urban & 59.6 & 623 \\
\hline Rural & 40.4 & 422 \\
\hline \multicolumn{3}{|l|}{ Education } \\
\hline Primary and gymnasium & 15.9 & 166 \\
\hline Vocational & 25.1 & 263 \\
\hline Secondary & 31.2 & 326 \\
\hline Higher/academic & 27.8 & 291 \\
\hline
\end{tabular}

lent in the oldest age group ( $0.9 \%$ in men, 0 in women). There were more ENDS users in urban than rural areas ( $4.1 \%$ of men and $0.9 \%$ of women in urban areas vs. $1.5 \%$ of men and $0.5 \%$ of women in rural areas). The highest prevalence of ENDS use was found in men with a secondary education $(4.3 \%)$, and in women with a primary education (1.2\%) (Table 2).

Data showed a weak overlap between ENDS use and the use of conventional cigarettes. Three percent of men (3.1\%) were daily (regular) dual users of conventional cigarettes and ENDS, and 3.5\% of men using conventional cigarettes used ENDS in exceptional situations (occasionally). There were no daily (regular) ENDS users among smoking women, but $3.1 \%$ of women who smoked conventional cigarettes also used ENDS in exceptional situations (occasionally) (Table 3 ).

\section{DISCUSSION}

The prevalence of daily (regular) ENDS use in Poland in 2019 was 3\% among men and less than 1\% among women. On this basis we estimated that in the

TABLE 2. ENDS use by gender, age group, residence and education

\begin{tabular}{|c|c|c|c|c|c|c|}
\hline \multirow{2}{*}{$\begin{array}{l}\text { Do you use electronic } \\
\text { cigarette } \\
\text { (e-cigarette)? }\end{array}$} & \multicolumn{2}{|c|}{ Yes, regularly } & \multicolumn{2}{|c|}{$\begin{array}{l}\text { Yes, but only in exceptional } \\
\text { situations, occasionally }\end{array}$} & \multicolumn{2}{|c|}{ No } \\
\hline & $\%$ & $n$ & $\%$ & $n$ & $\%$ & $n$ \\
\hline Men & 3.0 & 15 & 1.6 & 8 & 95.4 & 473 \\
\hline \multicolumn{7}{|l|}{ Age } \\
\hline 20-44 years old & 5.3 & 12 & 3.1 & 7 & 91.6 & 206 \\
\hline 45-64 years old & 1.2 & 2 & 0.6 & 1 & 98.1 & 159 \\
\hline 65 years old and older & 0.9 & 1 & 0 & 0 & 99.1 & 108 \\
\hline \multicolumn{7}{|l|}{ Residence } \\
\hline Urban & 4.1 & 12 & 1.4 & 4 & 94.6 & 278 \\
\hline Rural & 1.5 & 3 & 2.0 & 4 & 96.5 & 195 \\
\hline \multicolumn{7}{|l|}{ Education } \\
\hline Primary and gymnasium & 2.4 & 2 & 3.6 & 3 & 94.0 & 78 \\
\hline Vocational & 2.6 & 4 & 0.6 & 1 & 96.8 & 149 \\
\hline Secondary & 4.3 & 6 & 1.4 & 2 & 94.3 & 133 \\
\hline Higher/academic & 2.6 & 3 & 0.9 & 1 & 96.6 & 112 \\
\hline Women & 0.7 & 4 & 0.7 & 4 & 98.6 & 544 \\
\hline \multicolumn{7}{|l|}{ Age } \\
\hline 20-44 years old & 1.3 & 3 & 0.9 & 2 & 97.8 & 225 \\
\hline 45-64 years old & 0.5 & 1 & 0.5 & 1 & 99.0 & 194 \\
\hline 65 years old and older & 0 & 0 & 0.8 & 1 & 99.2 & 125 \\
\hline \multicolumn{7}{|l|}{ Residence } \\
\hline Urban & 0.9 & 3 & 0.6 & 2 & 98.5 & 326 \\
\hline Rural & 0.5 & 1 & 0.9 & 2 & 98.6 & 218 \\
\hline \multicolumn{7}{|l|}{ Education } \\
\hline Primary and gymnasium & 1.2 & 1 & 0 & 0 & 98.8 & 82 \\
\hline Vocational & 0.9 & 1 & 0 & 0 & 99.1 & 107 \\
\hline Secondary & 1.1 & 2 & 1.1 & 2 & 97.8 & 181 \\
\hline Higher/academic & 0 & 0 & 1.1 & 2 & 98.9 & 173 \\
\hline
\end{tabular}


general adult ( 20 years of age and more) population in Poland there were around 700,000 daily ENDS users $(560,000$ men in a total population of $14,600,000$ men, and 140,000 women in a total population of $16,000,000$ women). However, it must be underlined here that these calculations extrapolate on very small numbers (although coming from a study based on a representative sample of population [2]), and therefore the margin of error might be significant. Because the numbers of adult ENDS users in Poland appear to be low, in order to characterise the population of ENDS users more accurately, detailed epidemiological study on a much larger sample would need to be carried out.

Nonetheless, the results of this study remain unique and very valuable as the scientific literature lacks reliable and good quality studies on prevalence of ENDS use that would be carried out on a sufficiently large random sample in Poland. The only exception are reports from studies conducted by the Chief Sanitary Inspectorate between 2013 and 2019 conducted on representative samples of around 1000 adults aged 15 years and above. Similarly to our study, they reported low prevalence of daily ENDS use among adults in Poland: 3\% in 2013 [18], $3 \%$ in 2015 [19], $2 \%$ in 2017 [20] and $4 \%$ (5.6\% in men and 3.0\% in women) in 2019 [21, 22].

Results from the latest Special Eurobarometer 506 [7] conducted in European Union Member States and United Kingdom in 2020 showed that the vast majority of European respondents (85\%) had never used ENDS, only $2 \%$ reported current use, and $14 \%$ reported ever trying ENDS. Men were slightly more likely than women to say they have at least tried ENDS (17\% compared with $12 \%$ ) and younger respondents were more likely to have at least tried them than older respondents. Smokers were much more likely to have tried ENDS (36\%) than those who had never smoked or who had quit (8\%). In 2020 Poland was among the countries with the lowest percentage of respondents who at least tried ENDS (6\%) and who currently use them (1\%). This stands in contrast with the 2014 Eurobarometer in which Poland was one of the countries with highest ENDS use [10]. In fact, since 2017 the largest decrease in percentage of respondents who at least tried ENDS once or twice was found in Poland $(-7 \%)$. However, as the report from the study in 2020 stated, the low prevalence does not correspond with available market data suggesting that Poland is one of the major EU markets for ENDS [7]. This discrepancy between low adult use and prominent market presence of ENDS in Poland requires further unpacking.

One potential explanation for the discrepancy between the low rates of ENDS use among adults in Poland, and the seeming market success of these products, could be ENDS use among Polish youth. Research suggests that ENDS can be particularly attractive for adolescents and young adults [23]. As conventional cigarettes fall out of fashion, and the prevalence of smoking
TABLE 3. ENDS use among daily smokers

\begin{tabular}{|l|c|c|c|c|c|c|}
\hline & \multicolumn{2}{|c|}{$\begin{array}{c}\text { Yes, } \\
\text { regularly }\end{array}$} & $\begin{array}{c}\text { Yes, but } \\
\text { only in } \\
\text { exceptional } \\
\text { situations, } \\
\text { occasionally }\end{array}$ & \multicolumn{2}{|c|}{ No } \\
\cline { 2 - 7 } & $\%$ & $n$ & $\%$ & $n$ & $\%$ & $n$ \\
\hline Overall & 3.1 & 7 & 3.5 & 8 & 93.4 & 212 \\
\hline Gender & \multicolumn{7}{|c|}{} \\
\hline Men & 5.4 & 7 & 3.9 & 5 & 90.7 & 117 \\
\hline Women & 0 & 0 & 3.1 & 3 & 96.9 & 95 \\
\hline
\end{tabular}

is decreasing in many countries, for example USA, Norway or UK [24], the industry increasingly targets ENDS to young people. This is also the case in Poland. The frequency of smoking has decreased among 15-year-olds in Poland between 1998 and 2014 from 22\% to 10\% among boys and $14 \%$ to $10 \%$ among girls [24]. The Polish report from the survey "Health Behaviour in School-Aged Children" in 2018 showed that among youth aged 15 years old who declared tobacco smoking, $5.6 \%$ of them were daily smokers (6.5\% of boys and $4.8 \%$ of girls) [25]. At the same time, the report of the WHO Regional Office for Europe on the Global Youth Tobacco Survey results showed that between 2014 and 2019 among 18 countries of the European Region, current use of ENDS among students aged 13-15 years was the highest in Poland (23.4\%) in 2016 [26]. It means that in 2016 in the general population of youth aged 13-15 years in Poland there were around 257,400 current ENDS users.

It is worth noting that the dynamic of ENDS use in Poland, with low rates among adults and high rates among youth, drastically contrast with countries such as the UK, where ENDS have become a popular smoking cessation tool. UK public health policy has led to the highest use of ENDS in the adult population in Europe, but the frequency of use of ENDS by children remains low, with $83 \%$ of youth (11-18 years old) in the UK in 2020 never having tried ENDS, and only $4.8 \%$ classified as current users [27]. Poland and the UK seem to represent two extremes and can provide interesting case studies in the ongoing public health debate about the usefulness of ENDS as smoking cessation products [28-30].

Another potential confounder in the Polish case is that Poland in the last decades has been a country with particularly strong anti-tobacco climate, as demonstrated by Fagerstrom et al. (2001) [31]. It is likely that public awareness on tobacco harms might influence the perceptions of ENDS among Polish adults. Another potential reason for the low popularity of ENDS among adults in Poland might be the unique landscape of smoking cessation pharmacotherapy in the country. As ENDS were being introduced on the market, at the same time Poland has seen the growth in popularity of pure nicotine for 
cessation as well as the use of cessation drugs in the form of nicotine partial agonists acting on central nervous system based on cytisine [32]. Sales of smoking cessation drugs in Poland is one of the highest in Europe [32, 33] and continues to grow. After 2000, the quantity and value of sales of pure nicotine for medical use increased few times [34]. Nicotine replacement therapy (NRT) have been growing in the last decade when ENDS was introduced in Poland. In 2006 (the date of the ENDS appearance on the Polish market) they were slightly below a million packages and tripled by 2021 to about 3 million packages. Moreover, pharmaceutical forecasts indicate that sales of smoking cessation drugs will continue to grow in coming years [34]. Additionally, Poland remains the only country where cytisine is used on a population scale. Polish scientists introduced cytisine into the Polish market after a series of clinical reports and trials conducted between 2006 and 2011 confirmed its effectiveness $[32,33,35,36]$. The main placebocontrolled trial of cytisine for smoking cessation was published in New England Journal of Medicine in 2011 [36]. One could therefore form a hypothesis that due to the popularity of smoking cessation drugs in Poland, ENDS have not been successful in becoming an effective alternative for smokers looking to quit smoking. Instead, they have grown in popularity among nicotine-naïve children.

Accurate and continuous monitoring and surveillance continues to be a priority. ENDS on the Polish market, as in most countries, are promoted and sold under the misleading name of "e-cigarettes". From many points of view, conventional cigarettes are a completely different product than ENDS, but they often seem to be conflated in the literature. For example, the report of the Polish Institute of Public Health - National Hygiene Institute combines the percentage of people using ENDS to the percentage of people smoking conventional cigarettes, which makes it difficult to interpret the results and plan appropriate public health responses [37].

This paper has several limitations. First, the study was not devoted directly to ENDS use, and questions about ENDS were part of a large questionnaire concerning different topics. There was only one, not previously validated, question about ENDS use that was used to determine daily and occasional ENDS users. Not using standard protocol reduces the possibility of comparing the results from different studies. It is likely that due to the phrasing of the question, people who declared that they have ever tried ENDS, but do not continue to use them, may have mistakenly been categorized as daily (regular) ENDS users instead of ever users. Furthermore, the study was conducted on a relatively small sample of population which made more comprehensive statistical analysis impossible. It is necessary for Poland to introduce systematic and good quality annual surveys on ENDS use with more comprehensive questionnaires to monitor ENDS use in adult population in order to be able to plan potential effective prevention strategies.

\section{CONCLUSIONS}

Poland was a country with one of the highest rates of cigarette consumption in the world in the 1980s. Now it is one of the countries with the fastest decline of smoking rates and tobacco-caused ill health, as evidenced by the significant decrease in the incidence and mortality of tobacco-related diseases in Poland.

Our study showed that despite a decline in conventional cigarette smoking, the prevalence of ENDS use among adults in Poland is low and it did not increase in the recent years. This stands in contrast with research showing that Poland has some of the highest rates of ENDS use among children. Unlike in countries such as the UK, in Poland ENDS seem not to have a prominent role in facilitating smoking cessation but have rather been avenues for the industry to attract new nicotine naïve consumers, especially youth. This is a public health challenge that requires appropriate regulatory and educational responses. However, in order to develop such appropriate responses, the system of monitoring of ENDS use in Poland needs to be improved, as the existing data for Poland remains scattered, of poor quality, and based on small samples.

\section{ACKNOWLEDGMENTS}

Authors of the manuscript would like to thank the $\mathrm{Pu}$ blic Opinion Research Center (Centrum Badania Opinii Społecznej) for collaboration and data release.

\section{DISCLOSURE}

The authors report no conflict of interest.

\section{References}

1. Zatoński M, Zatoński WA, Przewoźniak K, Jaworski M. The significance and impact of the Polish Anti-tobacco Law. J Health Inequal 2016; 2 (1): 32-35.

2. Janik-Koncewicz K, Zatoński W, Zatońska K, et al. Cigarette smoking in Poland in 2019: the continuing decline in smoking prevalence. J Health Inequal 2020; 6 (2): 87-94.

3. Zatoński WA, Janik-Koncewicz K, Zatoński M, Wojtyła A. Health decline in Poland after 2002: response to a recent analysis of the changes in disease burden in Poland. J Health Inequal 2021; 7 (1): 2-6.

4. Zatoński WA, Zatoński M, Janik-Koncewicz K, et al. Hundred years of cigarette smoking in Poland: three phases of the tobacco epidemic. J Health Inequal 2017; 3 (2): 118-122.

5. Zatoński WA. One hundred years of health in Poland. J Health Inequal 2019; 5 (1): 11-19.

6. Zatoński WA, Janik-Koncewicz K, Zatoński M. Role of primary prevention in lung cancer control in Poland. J Thoracic Oncol 2021 [Ahead of print].

7. European Commission, Directorate-General for Health and Food Safety. Special Eurobarometer 506. Attitudes of Europeans towards tobacco and electronic cigarettes 2020. Available from: 
https://ec.europa.eu/commfrontoffice/publicopinion/index. $\mathrm{cfm} /$ survey/getsurveydetail/instruments/special/surveyky/2240 (accessed: 2 March 2021).

8. The First News. Up in smoke! Poland has second biggest decline in smokers in EU. Available from: https://www.thefirstnews. com/article/up-in-smoke-poland-has-second-biggest-declinein-smokers-in-eu-19748 (accessed: 5 June 2021).

9. Laverty AA, Filippidis FT, Varvadas CI. Patterns, trends and determinants of e-cigarette use in 28 European Union Member States 2014-2017. Prev Med 2018; 116: 13-18.

10. Filippidis FT, Laverty AA, Gerovasili V, Varvadas CI. Two-year trends and predictors of e-cigarette use in 27 European Union member states. Tob Control 2017; 26: 98-104.

11. Kapan A, Stefanac S, Sandner I, et al. Use of electronic cigarettes in European populations: a narrative review. Int J Environ Res Public Health 2020; 17: 1971.

12. WHO. Tobacco control. Factsheet. Available from: https:// www.euro.who.int/_data/assets/pdf_file/0009/422838/Tobacco-8-B-002.pdf (accessed: 10 June 2021).

13. US Food and Drug Administration. Vaporizers, E-Cigarettes, and other Electronic Nicotine Delivery Systems (ENDS). Available from: https://www.fda.gov/tobacco-products/products-ingredients-components/vaporizers-e-cigarettes-and-other-electronic-nicotine-delivery-systems-ends (accessed: 30 October 2020).

14. Breland AB, Spindle T, Weaver M, Eissenberg T. Science and electronic cigarettes: current data, future needs. J Addict Med 2014; 8 (4): 223-233.

15. Jankowski M, Minarowski $Ł$, Mróz RM, et al. E-cigarette use among young adults in Poland: prevalence and characteristics of e-cigarette users. Adv Med Sci 2020; 65 (2): 437-441.

16. Lewek P, Woźniak B, Maludzińska P, et al. E-cigarette use and its predictors: results from an online cross- sectional survey in Poland. Tob Induc Dis 2019; 17: 79.

17. Kissinger L, Lorenzana R, Mittl B, et al. Development of a computer-assisted personal interview software system for collection of tribal fish consumption data. Risk Anal 2010; 30 (12): 1833-1841.

18. TNS Polska dla Głównego Inspektoratu Sanitarnego. Raport z ogólnopolskiego badania ankietowego na temat postaw wobec palenia tytoniu. Available from: https://www.gov.pl/attachment/50f99e272ada-44f0-97f7-0b122a3c3bc4 (accessed: 24 January 2021).

19. TNS Polska dla Głównego Inspektoratu Sanitarnego. Raport $\mathrm{z}$ ogólnopolskiego badania ankietowego na temat postaw wobec palenia tytoniu. Available from: http://www.pis.lodz.pl/ data/other/gis_raport_tns_polska_2015.pdf (accessed: 24 January 2021).

20. Kantar Public dla Głównego Inspektoratu Sanitarnego. Raport z ogólnopolskiego badania ankietowego na temat postaw wobec palenia tytoniu. Available from: https://gis.gov.pl/wp-content/ uploads/2018/04/Postawy-Polak\%C3\%B3w-do-palenia-tytoniu-Raport-2017.pdf (accessed: 24 January 2021).

21. Kantar dla Głównego Inspektoratu Sanitarnego. Raport z ogólnopolskiego badania ankietowego na temat postaw wobec palenia tytoniu. Available from: https://gis.gov.pl/wp-content/ uploads/2018/04/Postawy-Polak\%C3\%B3w-do-palenia-tytoniu_Raport-Kantar-Public-dla-GIS_2019.pdf (accessed: 24 January 2021).
22. Pinkas J, Kaleta D, Zgliczyński WS, et al. The prevalence of tobacco and e-cigarette use in Poland: a 2019 nationwide cross-sectional survey. Int J Environ Res Public Health 2019; 16 (23): 4820.

23. Löhler J, Wollenberg B. Are electronic cigarettes a healthier alternative to conventional tobacco smoking? Eur Arch Otorhinolaryngol 2019; 276 (1): 17-25.

24. Zatoński WA, Aaro LE, Samdal O, Mazur J. Smoking- or nicotine-free generation, or both? What should be the public health priority? J Health Inequal 2016; 2 (2): 105-108.

25. Mazur J, Małkowska-Szkutnik A (eds.). Zdrowie uczniów w 2018 roku na tle nowego modelu badań HBSC [Youth Health in 2018 on the background of new model of HBSC survey]. Available from: http://www.imid.med.pl/files/imid/Aktualnosci/Aktualnosci/raport\%20HBSC\%202018.pdf (accessed: 11 June 2021).

26. WHO Regional Office for Europe. Summary results of the Global Youth Tobacco Survey in selected countries of the WHO European Region. Available from: https://www.euro.who.int/en/health-topics/disease-prevention/tobacco/publications/2020/summary-results-of-the-global-youth-tobacco-survey-in-selected-countriesof-the-who-european-region-2020 (accessed: 14 June 2021).

27. Action on Smoking and Health. Use of e-cigarettes among young people in Great Britain. Available from: https://ash. org.uk/information-and-resources/fact-sheets/statistical/useof-e-cigarettes-among-young-people-in-great-britain-2020/ (accessed: 14 June 2021).

28. McKee M, Bareham D. E-cigarettes and English exceptionalism. J Health Inequal 2018; 4 (2): 68-69.

29. McNeill A. Balancing the risks and benefits of e-cigarettes through regulations. J Health Inequal 2018; 4 (2): 70-72.

30. Rigotti NA. Randomized trials of e-cigarettes for smoking cessation. JAMA 2020; 324 (18): 1835-1837

31. Fagerstrom K, Boyle P, Kunze M, Zatoński W. The anti-smoking climate in EU countries and Poland. Lung Cancer 2001; 32: 1-5.

32. Zatoński WA, Janik-Koncewicz K, Stępnicka Z, et al. History of smoking cessation treatment in Poland - the strengthening role of cytisine as the most effective and safe pharmacotherapy. J Health Inequal 2020; 6 (2): 116-123.

33. Zatoński W, Zatoński M. Cytisine versus nicotine for smoking cessation. N Engl J Med 2015; 372 (11): 1072.

34. Środki antynikotynowe [Smoking cessation drugs]. Open Health Care System 2020; 10: 69-74.

35. Zatonski W, Cedzynska M, Tutka P, West R. An uncontrolled trial of cytisine (Tabex) for smoking cessation. Tob Control 2006; 15: 481-484.

36. West R, Zatoński W, Cedzyńska M, et al. Placebo-controlled trial of cytisine for smoking cessation. N Engl J Med 2011; 365 (13): 1193-1200.

37. Wojtyniak B, Gorynski P (eds.). Health status of Polish population and its determinants, 2020. Available from: http://bazawiedzy.pzh.gov.pl/wydawnictwa (accessed: 14 June 2021).

\section{AUTHORS' CONTRIBUTIONS}

KJK and WZ prepared the concept of the paper. KJK analysed data and prepared the first draft of the article. All authors contributed to the final version of the publication and approved the final manuscript. 